\title{
Weather conditions during the blossoming period and their effect on the yield of three cultivars of blackcurrant (Ribes nigrum L.)
}

\author{
Jan Grabowski ${ }^{1}$, Zdzisław Kawecki ${ }^{2}$, \\ Anna Bieniek ${ }^{2}$, Zofia Tomaszewska ${ }^{2}$ \\ ${ }^{1}$ Department of Meteorology \\ ${ }^{2}$ Department of Horticulture \\ University of Warmia and Mazury \\ Prawocheńskiego 21, 10-957 Olsztyn, Poland \\ e-mail: anna.bieniek@uwm.edu.pl
}

Key words: blackcurrant, cultivars, weather elements, yield

\begin{abstract}
This study presents the influence of major weather factors during the blackcurrant blossoming period on the yields of the 'Ojebyn', 'Titania' and 'Roodknop' cultivars, cultivated in Warmia (Olsztyn). The study was conducted for five years (2003-2007). Among the factors analysed were the currant yield, the duration of the blossoming period, average daily air temperature, the number of days with frost at the height of $2 \mathrm{~m}$ and at the ground level, total rainfall during the blossoming period and the number of days with rainfall during the blossoming period.

The statistical analysis of particular weather factors has shown that the number of days with frost contributed significantly to the yield of the fruit. A linear correlation analysis has shown that the yield of the three examined cultivars of blackcurrant depended on variable weather conditions during the blossoming
\end{abstract}


period. The yield of the 'Ojebyn' cultivar was significantly correlated with the duration of the blossoming period, the number of days with frost and the number of days with rainfall. A significant correlation in the 'Titania' cultivar was found with the number of days with frost and with the total amount of rainfall during the blossoming period. The fruit yield from the 'Roodknop' cultivar in the five-year period under study depended only on one variable: the duration of the blossoming period. The highest yield was obtained from the 'Titania' cultivar.

\section{INTRODUCTION}

Currant, especially blackcurrant, is a relatively commonly grown fruit, both by professional producers and by amateurs. The annual output in Poland exceeds 100 thousand tonnes. The yield depends not only on the quality of cultivation, but mainly on the weather conditions during the blossoming period (Kawecki et al. 2006).

Earlier studies by the authors (Grabowski et al. 2007), which were conducted with different fruit-bearing plants, showed that there was a relationship between the yield and weather conditions during the blossoming period, especially the air temperature, the amount and distribution of rainfall, relative air humidity, solar exposure and the number of days with frost.

The aim of this study was to find out how the selected weather factors related to the air temperature and rainfall during the blossoming period affected the yield of blackcurrant of the following cultivars: 'Ojebyn', 'Titania' and 'Roodknop'.

\section{MATERIAL AND METHODS}

Bushes of the 'Ojebyn', 'Titania' and 'Roodknop' blackcurrant cultivars were used as the study material. The plantation was set up at the UWM Garden in Olsztyn in 1999 for manual harvest, on green-brown, quality class six podsolic soil. The bushes were planted with a spacing of $3 \times 1.5 \mathrm{~m}$ in a row arrangement. The obtained yield was an arithmetic average calculated from 40 bushes growing at a flat land site, without any soil variability. The inter-rows were maintained as bare fallow. The cultivation, fertilisation and plant protection procedures were performed according to the framework schedule.

The study analysed the influence of several weather factors on yield during the blossoming period of the three blackcurrant cultivars. The weather data used in the statistical calculations were obtained from the Chair of Meteorology and Climatology of the University of Warmia and Mazury in Olsztyn. The following variables were taken into account: 
$\mathrm{Y}$ - blackcurrant yield,

$\mathrm{X}_{1}$ - duration of the blossoming period (days),

$\mathrm{X}_{2}-$ average daily air temperature $\left({ }^{\circ} \mathrm{C}\right)$,

$\mathrm{X}_{3}-$ number of days with frost at the standard level $(2 \mathrm{~m})$,

$\mathrm{X}_{4}-$ number of frost at the ground level $(5 \mathrm{~cm})$,

$\mathrm{X}_{5}-$ total rainfall during the blossoming period $(\mathrm{mm})$,

$\mathrm{X}_{6}$ - number of days with rainfall.

As the bushes were up to $1.5 \mathrm{~m}$ in height, the plants could be exposed to frost both at the standard level $(2 \mathrm{~m})$ and at ground level $(5 \mathrm{~cm})$. Consequently, both levels were taken into account in the statistical calculations. The analysis also included the total rainfall during the blossoming period and the number of days with rainfall, as those factors affect bee flight, which, in turn, contributes to more effective flower pollination (Lipiński 1982).

The relationship between the described variable ( $\mathrm{Y}$ - yield) and the weather factors affecting its value was determined by a multiple regression analysis at the level of significance $\mathrm{p}=0.05$.

The model adopted to show the relationship has the following form:

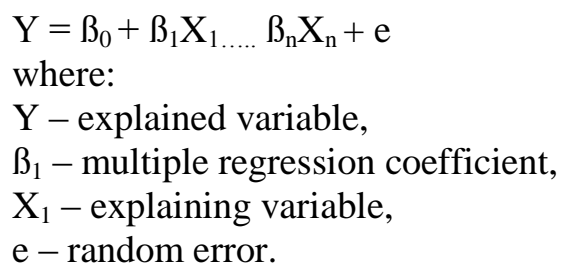

Moreover, the influence of the examined variables (weather factors) on the yield of particular blackcurrant cultivars was shown with the use of linear regression analysis.

\section{RESULTS AND DISCUSSION}

Table 1 shows the variability of yield and the weather factors in the blackcurrant blossoming period in the years 2003-2007.

The average yield in the analysed five-year period was equal to $2.88 \mathrm{t} \mathrm{ha}^{-1}$ ( $1.29 \mathrm{~kg}$ per bush) for the 'Ojebyn' and Roodknop' cultivars, and $3.60 \mathrm{t} \mathrm{ha}^{-1}$ (1.62 kg per bush) for the 'Titania' cultivar. The differences in the yield were a result of their natural productivity, which is genetically determined (Gwozdecki and Chlebowska 1988, Gwozdecki et al. 1988). In addition, the yields of Roodknop' and 'Titania' were the least scattered. Despite the passage of time, Gwozdecki and Chlebowska (1992) regard those cultivars, especially 'Roodknop 504', as valuable for cultivation. 


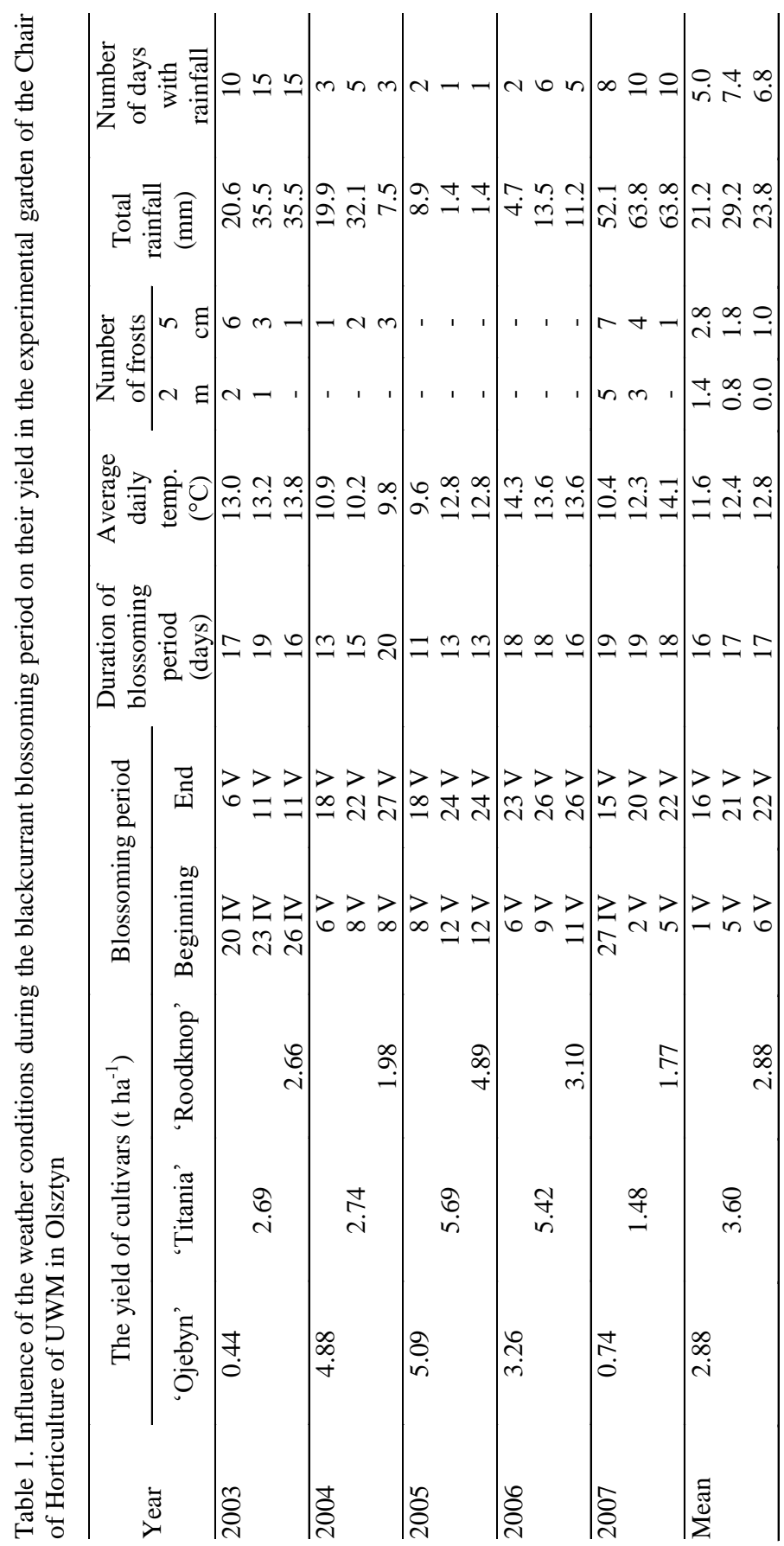


The pomological characteristics of the cultivars indicate that they are relatively resistant to spring frost and cool weather during the blossoming period (Gwozdecki and Chlebowska 1992). A study conducted by Gwozdecki (1994) showed that boosting pollination by shaking sprouts during the blossoming period did not increase the amount of fruit produced by self-pollination. Good, frost-free weather and bee pollination, rather than wind, seem to affect fruit yield most positively.

Among the examined cultivars, the highest yield variability was observed in the 'Ojebyn': $0.44 \mathrm{t} \mathrm{ha}^{-1}\left(0.19 \mathrm{~kg} \mathrm{bush}^{-1}\right)$ in 2003 and $0.74 \mathrm{t} \mathrm{ha}^{-1}\left(0.33 \mathrm{~kg} \mathrm{bush}^{-1}\right)$ in 2007. In 2005, $5.09 \mathrm{t}$ of fruit was harvested from 1 ha $\left(2.29 \mathrm{~kg} \mathrm{bush}^{-1}\right)$. High fluctuations of yield in the cultivar were caused by frost during the blossoming period that started the earliest, i.e. on 20 April (while the average beginning of flowering was 1 May) and lasted the shortest (16 days).

In individual years of the five-year period of the study, the duration of the blackcurrant blossoming period varied greatly. The earliest blossoming in the studied cultivars was observed at the beginning of the third 10 days of April in 2003, while the latest occurred at the beginning of the second 10 days of May in 2005. The duration of the blossoming period ranged from 11 days for 'Ojebyn' in 2005 to 20 days in 2004 for 'Roodknop'. Earlier studies by Kawecki et al. (1992) and Grabowski et al. (2007) showed that a shift of particular phenophases in plants growing in Warmia and Mazury, especially the beginning of vegetation and blossoming periods, can in some cases be as long as 30 days.

The average air temperature when the plants are in bloom depends on when the blossoming period occurs (Atlas klimatyczny 2001). In this study, the lowest average daily air temperature during the blossoming period of the 'Ojebyn' bushes was $11.6^{\circ} \mathrm{C}$, and the highest was $12.8^{\circ} \mathrm{C}$ for 'Roodknop'. The 'Roodknop' bushes blossomed later than others (6 May - 22 May). Rejman (1994) reports that 'Roodknop' bushes blossom for 10 to 21 days and this may be at the end of April or the beginning of May.

One of the negative features of the agri-climatological conditions in the northeast of Poland is the late occurrence of a spring frost. In extreme cases it may even occur at the beginning of June (Atlas klimatyczny 1990).

As has been stated above, the weather conditions in the years 2003-2007 indicate that a low yield of the examined cultivars was mainly caused by frost at the standard level $(2 \mathrm{~m})$ and at the ground level $(5 \mathrm{~cm})$, observed during the blossoming period. Flower pollination was also affected by total rainfall and the number of days with rainfall when the plants were in bloom. Rainfall during the period prevents bee flights, which condition effective pollination (Kawecki et al. 1992). As was shown by the study conducted by Lipiński (1982), blackcurrant is a good nectar flow and its flowers are readily visited by bees, provided the temperature is higher than $10^{\circ} \mathrm{C}$ and there is no rain. 
The differences in some weather factors during the blossoming period stem from the peculiarities of the climate of Poland (Kożuchowski and Wibig 1988). They are also caused by the greenhouse effect, which has been particularly manifested in recent years and is caused by human activities; this has been confirmed in $94 \%$ of cases by the latest ITCC report (Fourth Assessment Report Climate Change 2007).

The comprehensive effect of the examined weather factors on blackcurrant yield has been shown with the use of multiple regression analysis. The calculations produced the following formula:

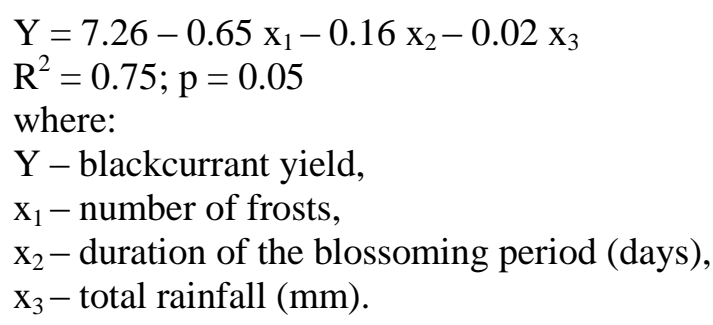

The formula, which determines the effect of weather conditions during the blackcurrant blossoming period on its yield, indicates the number of days in which frost was a variable that significantly affected the yield.

The determination coefficient $\mathrm{R}^{2}$ for the presented formula explains in $75 \%$ the relationship between the blackcurrant yield and the weather conditions during the blossoming period.

The results of the linear correlation analysis (Tab. 2) indicate that the yield of the examined blackcurrant cultivars was significantly affected by various weather factors during the blossoming period. The yield of 'Ojebyn' was significantly correlated with the duration of the blossoming period, the number of days with frost and the number of days with rainfall. The yield of 'Titania' was significantly correlated with the number of days with frost and the total rainfall during the blossoming period. And the yield of 'Roodknop' depended only on one variable: the duration of the blossoming period. The effect of the other weather factors was either positive or negative, but was always statistically insignificant.

Table 2. Coefficients of linear correlation ( $\mathrm{r}$ ) between the yield of blackcurrant $(\mathrm{Y})$ and random variables (X) describing conditions during the blossoming period

\begin{tabular}{llccccc}
\hline \multirow{2}{*}{ Cultivar } & \multicolumn{7}{c}{ Weather factors } \\
\cline { 2 - 7 } & $\mathrm{X}_{1} * *$ & $\mathrm{X}_{2}$ & $\mathrm{X}_{3}$ & $\mathrm{X}_{4}$ & $\mathrm{X}_{5}$ & $\mathrm{X}_{6}$ \\
\hline 'Ojebyn' & $-0.83^{*}$ & -0.33 & - & $-0.91^{*}$ & -0.61 & $-0.92^{*}$ \\
'Titania' & -0.54 & 0.44 & - & $-0.97 *$ & $-0.95^{*}$ & -0.66 \\
'Roodknop' & $-0.91^{*}$ & 0.13 & - & -0.66 & -0.62 & -0.49 \\
\hline
\end{tabular}

*Assessment of the correlation coefficient significance at $\mathrm{p}=0.05$

**Explanations as in the methodology section 


\section{CONCLUSIONS}

1. The data presented in the study indicate that the highest yield was obtained from 'Titania'.

2. The yield in individual years was greatly affected by frost during the blossoming period.

3. The 'Titania' and 'Roodknop' cultivars blossomed later and the period when they were in bloom lasted longer, which affected the yield.

4. The occurrence of rainfall and its duration negatively affected the yield of 'Ojebyn' and 'Titania'.

\section{REFERENCES}

ATLAS KLIMATYCZNY ELEMENTÓW I ZJAWISK SZKODLIWYCH DLA ROLNICTWA W POLSCE, 1990. Wyd. IUNG Puławy, AR Szczecin.

ATLAS KLIMATYCZNY RYZYKA UPRAWY ROŚLIN W POLSCE, 2001. Wyd. AR Szczecin, Uniwersytet Szczeciński.

Fourth ASSESSMENT RePORT Climate ChANGe, 2007. Intergovernmental Panel on Climate Change. Synthesis Report.

GRABOWSKI J., KAWECKI Z., TOMASZEWSKA Z., 2007. Meteorological conditions of the blooming of nanking cherry (Prunus tomentosa Thunb.) and their impact on the yield. Folia Hort. 19(1): 45-52.

GWOZDECKI J., 1994. Wpływ otrząsania krzewów porzeczki czarnej w czasie kwitnienia na wytwarzanie owoców. 33 Ogólnopol. Nauk. Konf. Sad. Cz. II. Skierniewice, 30 sierpnia - 1 września: 333-335.

GWOZDECKI J., CHLEBOWSKA D., 1988. Wstępna ocena wartości produkcyjnej 15 odmian porzeczki czarnej. Prace Inst. Sad. i Kwiac. S.A. 28: 59-67.

GWOZDECKI J., CHLEBowsKa D., 1992. Odmiany porzeczki czarnej i prawo do ich rozmnażania. Konf. Porzeczkowa. Skierniewice, 23 czerwca: 1-6.

Gwozdecki J., PierzGa Z., RadaczyŃSKa Z., TrojszczaK T., Podgórska H., BALON M., 1988. Ocena wartości produkcyjnej porzeczki czarnej w różnych rejonach Polski. Prace Inst. Sad. i Kwiac. S.A. 28: 67-74.

KAWECKI Z., KoZŁowsKi W.M., TOMASZEWSKA Z., 1992. Wzrost i plonowanie 8 odmian porzeczki czarnej uprawianej $\mathrm{w}$ warunkach klimatycznych Ełku i Olsztyna. Acta Agricult. 54: 205-214. 
Kawecki Z., Bieniek A., Kopytowski J., Siksnianas T., 2006. Preliminary assessment of productivity and fruit quality of Lithuanian and Ukrainian cultivars of blackcurrant under the climatic conditions of Olsztyn. J. Fruit Ornam. Plant Res. 14: 75-80.

KOŻUCHOWSKI R., WIBIG J., 1988. Kontynentalizm pluwialny w Polsce: zróżnicowanie geograficzne i zmiany wieloletnie. Zakład Narodowy im. Ossolińskich, Wrocław: 1-102.

LIPIŃSKI M., 1982. Pożytki pszczele. PWRiL, Warszawa.

REJMAN A., 1994. Pomologia. PWRiL, Warszawa.

\section{WARUNKI METEOROLOGICZNE W OKRESIE KWITNIENIA A PLONOWANIE KRZEWÓW TRZECH ODMIAN PORZECZKI CZARNEJ (RIBES NIGRUM L.)}

Streszczenie: W pracy analizowano wpływ ważniejszych elementów meteorologicznych występujących w okresie kwitnienia porzeczki czarnej odmiany 'Ojebyn', 'Titania' i 'Roodknop' uprawianych w warunkach Warmii (Olsztyn). Badania dotyczyły pięciolecia (2003-2007). Analizowano wpływ długości okresu kwitnienia, średniej dobowej temperatury powietrza, liczby przymrozków na poziomie $2 \mathrm{~m}$ i przy gruncie, sumy opadów w okresie kwitnienia oraz ilości dni z opadem w okresie kwitnienia na plon porzeczek. W wyniku przeprowadzonej analizy statystycznej poszczególnych elementów meteorologicznych stwierdzono, że istotną zmienną wpływająca na wielkość plonu była jedynie ilość dni z przymrozkami. Analiza korelacji liniowej wykazała, że plonowanie badanych trzech odmian porzeczki czarnej zależało od różnych zmiennych elementów meteorologicznych w okresie kwitnienia. Plonowanie krzewów odmiany 'Ojebyn' było istotnie skorelowane z długością okresu kwitnienia, ilością dni z przymrozkami i liczbą dni z opadem. U odmiany 'Titania' istotną korelację stwierdzono z liczbą dni z przymrozkami i wielkością opadów w okresie kwitnienia. Plon z krzewów odmiany 'Roodknop' w badanym pięcioleciu zależał tylko od jednej zmiennej - długości okresu kwitnienia. Najbardziej plenną odmianą w warunkach Warmii była 'Titania'. 